\title{
A "Die-Hard" Institution: The Organizational Structure of the National and Kapodistrian University of Athens
}

\author{
Zacharias E. Andreadakis
}

\begin{abstract}
Relying upon the assumptions and intellectual tools of the embeddedness approach in the organizational theory of higher education, this article analyzes the organizational structure of the National and Kapodistrian University of Athens (NKUA), parsing its institutional environment and its response to external pressures toward organizational completeness and global managerial scripts. The examination revolves around the dominant governance dilemmas in contemporary higher education organizational theory discourse, NKUA's selfportrait, and its self-professed organizational and administrative structure, as well as its intellectual positioning along the basic ideological and organizational categories of identity, hierarchy, and rationality. The discussion presents and negotiates the evidence for NKUA as an institution inclined toward a model of loose connections between classroom practices, administrative goals, and symbolically charged organizational rationales, which the promotes a sense of public service to the detriment of international neoliberalism.
\end{abstract}


This article aims to determine the degree of organizational completeness of the National and Kapodistrian University of Athens (henceforth, NKUA). At first sight, this might seem an impossible task. As entities participating in an intricate cognitive and social interplay (Brunsson and Sahlin-Andersson 2000), ${ }^{1}$ universities run across a wide continuum of disparate organizational logics. Moreover, dominated as they tend to be by transient socioinstitutional criteria, such as cultural symbols, myths, and legitimacy (Meyer and Rowan 1977; Meyer and Scott 1983; Perrow 1985; Meyer 2009; Zucker 1987), they persistently defy such reified, socially constructed categorizations. ${ }^{2}$ Consequently, organizational studies, especially within the field of higher education, have traditionally presented researchers with a morass of conflicting findings, spanning from scientific, instrumental, and purposeful organization models of Taylorism (Evans and Holmes 2013) to anarchical and whimsical models of arbitrary connection- the socalled loose coupling system - between educational practices, administrative goals, and organizational environment (Weick 1976; March 1984). At the heart of this debate lies the issue of trust in higher education's special organizational status (Musselin 2004, 2007; Seeber 2013; Seeber et al. 2015) and, consequently, the issue of whether to interpret any systemic stability or order within it as either the purposeful product of careful design or the application of preconceived solutions to emerging problems - the so-called garbage-can model (Cohen, March, and Olsen 1972; Cohen and March 1974; Olsen 2001, 2009; Brown 2010). ${ }^{3}$

In my analysis of NKUA's organizational status, I propose a synthesis between the two conflicting approaches (order versus anarchy) in higher education's organizational theory, building upon the intellectual artillery of the embeddedness 
perspective, a reconciliatory and pragmatic approach that suggests that the organizational behavior of rational actors is conditioned primarily by a given institutional environment and its existing networks - and only secondarily by instrumental and more carefully designed or predictable logics (Pusser, Slaughter, and Thomas 2006; Gumport 2012). Relying on the assumptions and intellectual tools of this approach, I focus primarily on the institutional level of our case study, NKUA, attempting to parse its institutional environment and the way it responds to external pressures toward organizational completeness.

In order to situate the analysis of our case study, the NKUA, let us begin by offering a broad, bird's eye view on the educational landscape of Greek higher education. In the past, there have been various descriptive analyses of Greece's educational landscape, with most prominent that of Antigone Papadimitriou (2011a). However, for the sake of accuracy in a rapidly changing educational environment, we follow the most recent report of the Ministry of Education (2016), which presents the descriptive and normative aspects of Greek higher education rather comprehensively. According to this government-issued document, higher education is provided by the Greek Higher

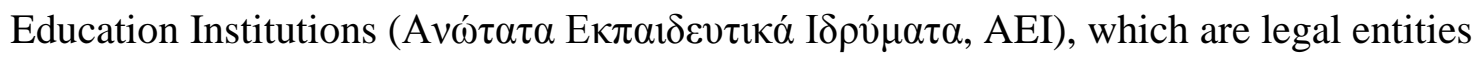
governed by public law, fully and autonomously self-governed, and subdivided into two parallel sectors: a) the University Sector, which includes the universities, the polytechnic schools, along with the higher schools of fine arts, which are referred to as universities; and b) the Technological Sector, which includes the Technological Education Institutions

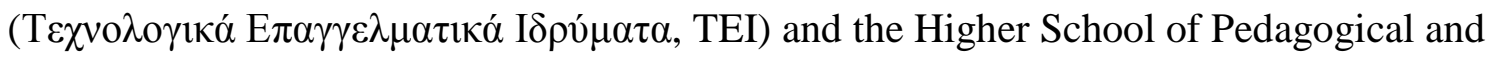

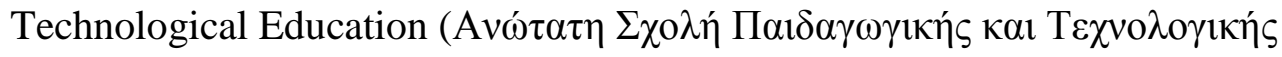




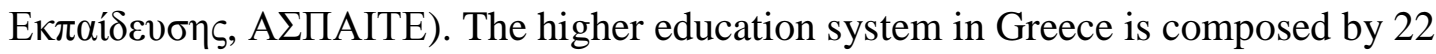
universities and 14 TEIs, with 268 and 168 departments, respectively, dispersed around all the larger cities of the country, with appendices in most community districts and with the largest part of institutions - the departments, the students, and the corresponding academic personnel/staff—being located in the metropolitan areas of Athens and Thessaloniki. The AEIs are significantly varied in terms of their size, age, specialization, and capability, with the oldest and most sizeable institutions being located in Athens and Thessaloniki, while the younger institutions are normally located in the country's smaller and more peripheral cities.

Moving toward investigating the normative fabric of the higher education's environment in Greece, the Ministry of Education offers a unique insight into the ideological priorities of the higher education sector by publishing a SWOT analysis report (Strengths, Weaknesses, Opportunities, Threats) of the higher education's sector as part of their strategic analysis and vision for the 2016-2020 period (Ministry of Education, 2016, 53-60). Starting from the strengths, the document emphasizes the historically open and free character of education, the large geographic and disciplinary variety offered by the various institutions, the slow but steady creation of a quality culture, along with their overall satisfactory status in world rankings, research outputs, and European alignment. Conversely, as part of the sector's weaknesses, infrastructure in student affairs/student aid comes high in the agenda, with an emphasis on lowering the large retention rates and starting to tracking student destinations, since currently there is a missing link between student education and the job market. What is more, financial penury is reported as another key deficit, preventing effective faculty-student ratios, 
encouraging so-called brain drain, and leading to fragmentation of human and material resources, along with introversion and lack of connection with the productive forces of society (see also Labrianidis 2014). On the opportunity side, the report registers a higher demand for higher education in Greece both from lifelong learning perspectives and from foreigners/immigrants. In addition, higher education is considered to display strong potential to benefit significantly from European Union research funds, the existence of strong institutional, national, and European support for educational matters, along with the possibility to profit greatly from European and international networks of quality assurance systems. Finally, the report concludes with possible threats to the sector, such as a reduction in retention rates due to financial pressures, the low birth rates that can lead to shrinking of the national educational population, the further aging of the academic personnel, who could not be replaced after they retired, and, finally, the great possibility of brain drain.

Within this intricate and idiosyncratic setting of higher education, I shall now zoom in to analyze the specific organizational environment of NKUA. To attain my research aims, I provide an analytical and empirical examination along three intersecting and often conflicting structural dimensions: the institution's governance direction, its existing organizational structure, and its administrative structure (Weick 1995; Henkel 2000; Enders 2002; Clegg, Courpasson, and Phillips 2006; Santiago et al. 2008; Seeber et al. 2015). In that respect, only a longitudinal study could possibly do justice to such an intricate nexus of so many intersecting institutional levels and agents (Pascarella 2006). However, realizing the sheer complexity of such a task allows us to see the challenging organizational structure of the university on multiple and intersecting levels, which 
invites its own distinct categories of assessment — categories that are often in tension with one another and do not allow for a neat and tidy answer. ${ }^{4}$ This intellectual exercise - that is, assessing the organizational status (and how real and complete an organization it is) of a structure of the size and complexity of NKUA - is nonetheless a crucial prerequisite for triangulating its position with regard to both its own expectations and the external realities that surround it.

NKUA was selected as a useful empirical site for this thought experiment on organizational status due to both its overwhelming size - one of the largest in Europe with over 120,000 students (NKUA 2016, 24) — and its old, public, and democratic institutional mission in a time of aggravated financial crisis (NKUA 2016, 8-10, 28), facts that complicate further attempts to attain a stable and coherent understanding of its organizational nexus.

To unpack the complicated and often arcane organizational structure of NKUA, perhaps the most representative source of its organizational logic is the recently published "self-portrait" of the university, which is a manifesto of its history, its status, and its intentions (NKUA 2016; see Figure 1). ${ }^{5}$ Relying upon a qualitative analysis of this document and in conjunction with the most recent government report on Greek higher education (Ministry of Education 2016), as well as NKUA's website, I reconstruct the university's organizational structures and its underlying logic in order ultimately to assess its organizational completeness.

\section{Structure and direction of intrainstitutional governance at NKUA}


To account for the organizational structure and direction of NKUA and, consequently, to evaluate its status according to four key university governance directions (see Larsen, Maassen, and Stensaker 2009), a brief account about the mission, the governance structure, and the legal framework of NKUA is expedient. As explicitly conditioned by both the Greek Constitution ([1975] 2008), Article 16, and Article 4 of Law 2009/2011, NKUA is a strictly, unequivocally, and fully self-governed legal entity of public law (NKUA 2016, 10), like all other AEIs in Greece. The mission of NKUA, as for all AEIs in Greece, comprises six main mandates: a) the promotion and dissemination of knowledge through teaching; b) the provision of lifelong education; c) the development of critical thought and skills; d) students' integration into the labor market; e) the promotion of educational cooperation; and f) the promotion of social and democratic values. ${ }^{6}$

As far as NKUA's structure of governance is concerned, authority and power are evenly distributed among three different bodies, with different responsibilities but equal status: the Senate, the Rector, and the Council of the University (see the Figure 1). The Rector is elected and appoints six Deputy Rectors from the entirety of the University population (faculty, staff, and students). The Council, in turn, comprises 15 members elected online by both the faculty and the students (all votes count equally). Of these 15 members on the Council, 9 members are internal ( 8 being internal professors with tenure and 1 being a student representative), and 6 members are external, proposed by the Rector and the internal members and appointed after an $80 \%$ vote consensus within the Council's voted representatives rank. It appears that the process is heavily merit-based, with the present external members being very distinguished faculty members of world- 
class universities, such as Princeton, MIT, Harvard, Cincinnati, and Sorbonne II-Paris: Panthéon-Assas. The Senate, as the most synthetic of the three decision-making organs, has the responsibility of enforcing a pragmatic consensus at all institutional levels and is composed of the Rector, the Senate's President (appointed once every two years by the Rector), the School Deans (8 in number), as well as the Departmental Presidents (12 in number), the Representatives of the Staff (4 in number), and the Representatives of Undergraduate and Graduate Studies (2 in number), each member having one vote.

In addition to these governance bodies, the various legal frameworks and initiatives have also shaped significantly NKUA's governance and can be seen as invaluable markers of the overall direction of governance of this institution and for its pressures toward change. There have been three main attempts to face these dilemmas in the postjunta Greek democracy: Law 1268/1982; ${ }^{7}$ Law 3374/2005; and Law 4009/2011. These reforms have admittedly aimed at creating a tighter coupling of the university's classroom practices, administrative goals, and its educational environment, which would, in theory, result in a more transparent, economically efficient, and effectively productive structure. This mandate for change has so far been best reflected in the recent reform law 4009/2011, which was inspired by the advice of the Organization for Economic Cooperation and Development (OECD 2011) on how to modernize fully and coalign Greece with most European countries. The new law was an attempt to enhance administrative transparency and to reduce costs, as well as to accelerate the graduation time of the student population by removing those who have been enrolled for more than 
double the time of their nominally expected graduation rate (see Zahariadis and Exadaktylos 2016, 68-70). However, in spite of broad parliamentary approval, the law has not been fully implemented, with the newly elected government rescinding several of its main legal provisions and essentially maintaining only the minimal role of enforcing the principal tenets of the preceding 1982 Law (Exadaktylos and Zahariadis 2014).

With these three structural dimensions of NKUA in mind-mission, governance structure, legal framework- let us now turn toward analyzing the four key governance directions of NKUA. The study conducted by Ingvild Larsen, Peter Maassen, and Bjørn Stensaker $(2009,5-8)$ is of immediate relevance, as it shows convincingly that within the broader, globally accelerated context and mandate for reforms in university governance, universities as a rule of thumb have to come to grips with four "stylized" dilemmas, which crystalize both the necessity and the design integrity of potential university governance reforms and modernization. These dilemmas develop between: a) representative democracy and organizational effectiveness (democracy or executive appointment); b) integrated and dual management structures; c) external and internal influence in institutional decision-making; and d) centralization and decentralization of authority.

Representative Democratic Participation. In NKUA, democratic elections are the constitutive, absolute norm for most of the appointment procedures in all three governing bodies (Senate, Council, and Rector). In fact, the only appointed rather than elected voting members are the six external members of the Council, who are proposed by the Rector and the internal members and who in order to be appointed have to receive an 
$80 \%$ vote of the Council's representatives. Therefore, a democratic voting practice still has the final word, since without a broad democratic consensus, these externally appointed members are annulled. Consequently, the democratic imperative of this institution is elevated, heeding a system of mutual checks and balances through biannual elections on all fronts (NKUA 2016, 3). Of course, not all parties have equal levels of power in the process, since students, via their student representatives, get only one vote at each level of study (one for undergraduate and one for graduate), even though they greatly outnumber the rest of the campus population. In contrast to student representatives, staff members are represented only in the Senate and, given their smaller absolute numbers, are in fact overrepresented with four votes. Nonetheless, the process of participation should be described overall as a highly democratic one, with emphasis on the element of representative consensus.

External Executive Participation. In spite of its great degree of democratic selfgovernance, however, NKUA, like all higher education institutions in Greece, is dependent upon the Ministry of Education for three of its main organizational features: a) its nominal budget; $b$ ) the number of incoming students; and c) any modifications in the budget, which have to be cosigned by the Minister and tend to provoke delays (see Ministry 2016, 28). This dependence complicates any attempt to see the university as an institution governed solely by autonomous institutional logics. The Ministry—in the spirit of the Bologna process of integration (Asderaki 2009) and in response to the wider international and European educational environment of pressures toward economy, efficiency, and effectiveness (Clark 1998; Neave 1998; Gornitzka 1999; Maassen and 
Olsen 2007; Larsen, Maassen, and Stensaker 2009; Tuchman 2009; Frølich 2011; Zmas 2015; Magolda 2016) — has occasionally initiated reforms that reflect market-oriented forces and dilemmas. Greek higher education—embedded in a recently reinforced, generally neoliberal paradigm (Pesmatzoglou 1994; Papandreou 1998; Louloudis 2010; Papadimitriou 2011b, 2015a, 2015b; Zahariadis 2013; Exadaktylos and Zahariadis 2014; European Parliament 2015; Zmas 2015; Ministry of Education in Greece 2016; Paliktzoglou, Giousmpasoglou, and Marinakou 2016; Triantidis 2016) — has not evaded such increasing contradictions between neoliberal and democratic processes.

These neoliberal pressures are reflected both in the inclusion (on merit-based criteria) of the six external members mentioned above and in the election of the Rector, which is a highly politicized and polarized process. The Rectors are strongly promoted by external political parties rather than solely by internal processes (Pesmatzoglou 1994; Papadoulis 2006), and the Rectors, in turn, appoint six nonvoting Deputy Rectors, who nevertheless have significant symbolic and informal influence over the governance direction. However, the broad democratic and elective basis of the overall system significantly restrains any individual advisor's attempts to swing the pendulum of governance in a more executive, managerial direction.

Concentration. The division of power is a key issue when describing the format and propensities of an organizational unit. As the most comprehensive governing body, the Senate is in charge of a long list of official issues. These include all ethics-related matters, as well as the official review and final approval to all the minutes for all meetings, to the appointments of the Rector and the members of the Council, and to all 
motions and petitions for university-wide change. The Rector's main responsibility, by contrast, is more applied policy-making; his or her energies are directed toward fiscal and fiduciary responsibilities and initiatives for the growth of the university's operation within and outside the country. Finally, the Council has as its main responsibility the definition and enforcement of academic quality standards, as well as the implementation of the university's agenda. These tasks and powers are very clearly distinct, yet power struggles and jurisdiction claims are not out of the question, especially regarding the enforcement of quality standards (Papadimitriou 2011a).

Unfortunately, this division of power and the description of individual duties by bodies and agents is not easily accessible in any detail in The National and Kapodistrian University of Athens: A Self-Portrait (2016) or on the university’s webpage. However, by searching thoroughly into the internal regulations and bylaws in Greek, this description of duties is available online and, in fact, in minute detail (see http://www.council.uoa.gr/symboylio/armodiothtes-symboylioy.html). A clear and more accessible description of the jurisdiction and assignments of each governing body could have reinforced the democratic imperative of an institution. In the internal regulations and bylaws, it appears that each of the three bodies is kept in check by the others, and this arrangement does not, at least structurally, incite or allow for persistent tensions. Hence, the concentration of power in the hands of different acting agents is comparatively low in NKUA.

Centralization. NKUA comprises 8 schools and 33 academic departments, with each school and department enjoying a great deal of nominal autonomy and decentralized 
control over research and teaching, except for the selection of its students and its nominal budget, which is arranged centrally by the Ministry of Education. The budget administration and resources management, however, are assigned to department heads, who are relatively free to use funds however they deem necessary for the promotion of their departments' interests. Similarly, the departments have a certain license regarding the hiring of both faculty and staff members, which has engendered suspicions of clientelism and nepotism in the past (Pesmatzoglou 1994; Keridis and Sfatos 1998; Altanopoulou, Dontsidou, and Tselios 2012). Last but not least, the schools and the department heads have a say in the Council and the Senate, a fact which has so far led to fragmentation among departments and the promotion of departmental interests instead of overall institutional and organizational ones. This is obvious, for instance, from the fact that NKUA itself promotes certain departments as traditional flagships, like Medicine and Agriculture, further underscoring the rather low degree of centralization at NKUA (2016, 4-5).

Ultimately, it appears as if modernization processes at all four levels, including managerialism and market pressures, have left the NKUA largely intact. Its mission, structure, legal framework, and overall governance direction do not seem to take serious account of nor to internalize either external pressures or the standard sources of intrainstitutional conflict (means versus goals), as often happens in organizations that strategically modify their missions (Oliver 1991). Of course, one could argue that the promotion of the discourse of skills for the labor market indicates the opposite, namely, the dogma of academic capitalism (Muller and Young 2014). Furthermore, the inclusion of prestigious external academic members in the university's governance could be 
understood as a move toward the more market-like orientation of a prestige academic economy (Tuchman 2009). Finally, we should not underestimate the backstage, hidden intentions of organizations, which are not visible in document analysis or in formal approaches but can nonetheless powerfully inform the practices of an organization (Brunsson 1989). However, the overall picture presented of NKUA's mission is heavily inclined toward the promotion of public good, free intellectual inquiry through selfgovernance, openness and inclusiveness, all pitted against pressures to internalize market logics and become self-sustainable, subordinate to external pressures, or a mere service provider for clients. ${ }^{8}$

\section{Organizational structure}

To describe the organizational structure of NKUA, I follow Burton Clark's (1983, 37-49) working hypothesis that the "operational units" of an institution can be analyzed by means of its horizontal and vertical division of labor, a model that, as will become clear, fully applies to our case institution.

NKUA's organizational structure comprises both academic organizational units and nonacademic ones. First, the academic units, divided according to the established model of knowledge divisions, ${ }^{9}$ are clearly marked and include 8 schools: 1) the School of Theology; 2) the Law School; 3) the School of Economics and Political Sciences; 4) the School of Education; 5) the School of Science; 6) the School of Physical Education and Sport Science; 7) the School of Health Sciences; and 8) the School of Philosophy. Within these 8 Schools of the University are 33 subjacent academic departments, each of 
which offers and implements a corresponding undergraduate study program, as well as several MA and $\mathrm{PhD}$ programs.

As shown above, NKUA displays a large degree of decentralization. By consequence, given the lack of an explicit or clearly outlined operational protocol, every department organizes and engages with the primary processes of research and teaching in its own way, creating it own chains of hierarchies and reporting techniques from faculty to dean to Rector. Every department seems to follow its own protocol and disciplinary loyalties regarding how to pursue their disciplinary primary processes (Becher and Trowler 2008), with no readily identifiable organizational pattern (Pezmatzoglou 1994; Stamoulas 2006; Papadimitriou 2011b).

In that sense, NKUA is an institution that appears to favor the flat organizational structure of loosely coupled educational, administrative, and organizational parts in its academic units. This orientation perhaps counteracts its possible characterization as an organization that aspires to the completeness of a market-oriented organization, since it is does not operate in a top-down and directive manner (Clark 1983). Nevertheless, such influences can still be detected allowing NKUA to strike a balance between a bottom-up, academically open, curiosity-driven orientation and a top-down, utilitarian, technocratic outlook, with rigid division of labor and primary focus on results (Enders 2002). Research is organized around the various departments and disciplines; a key dimension of this organization is the active participation of students in the process. NKUA could be best characterized as a research institution, where the production of research is the first priority, and teaching and research inform each other in the educational process, harking back ideologically (but not organizationally, since we are dealing with departmental 
structures rather than chair structures) to the Humboldtian example of formative education through research (Bildung durch Wissenschaft). This ideological orientation defers modern educational practices and market logics (Frølich 2011; Altanopoulou, Dontsidou, and Tselios 2012; Fohrmann 2016;).

However, contradictory evidence indicating a more purposeful organizational structure exists at NKUA, as well, especially with regard to the university's engagement with public outreach (standardly now termed as its "third mission") and the organizational support around its less developed academic initiatives (Jaeger and Kopper 2014). First, the existing infrastructure - growing with public and European investment funds for library resources, the establishment of research centers, administrative support for the facilitation of resource acquisition, financial support by the state, partnerships with external centers and institutions, museums, and so forth — is committed to the pursuit of research primarily at the institutional level (Ministry of Education 2016), in spite of the harsh financial realities that undercut this ambition, as shown by both NKUA (2016) and the Ministry of Education (2016).

Second, NKUA has developed a brand-new organizational structure through the Innovation and Entrepreneurship organizational unit initiative, first established in 2015. This initiative aims to provide a fresh outlook on the connection between the university sector and entrepreneurial/business activities. The Innovation and Entrepreneurship unit has established both an open undergraduate competition for new business ideas (Innovathens 2016) and an open-ended, ongoing survey of young entrepreneurs' perspectives on how business and youth initiatives are pursued in Greece (the Youth Entrepreneurship Barometer, in conjunction with the National Bank of Greece). This 
umbrella organization for the competitive mentoring and sponsorship of young students with entrepreneurial ambitions is without precedent in Greece; its full potential has yet to be explored.

Finally, a new organizational addendum was created by way of a server for fostering an alumni network in the University of Athens, which spans across several, though yet not all, of its departments (https://alumni.uoa.gr/). Its purpose as a newsfeed generator and as a source of connectivity among alumni is a new development of the university's logic and seems to enhance transparency and accountability via its constant publication of job announcements, scholarships, doctoral defense events, and so forth. Its full import remains to be seen, but it seems to represent a step toward an efficiency and effectiveness regime, while still supporting loyalty to the university's identity. In addition, NKUA has reinvigorated the use of research and development parks. Specifically, the Leukippos Research and Development Park was established as early as 1992, under the supervision of NKUA's Department of Physics (http://tepalefkippos.demokritos.gr/); today it hosts approximately 30 high-tech businesses in fields such as nanotechnology, pharmaceuticals, green energy, and software engineering. The park administration offers both technological support when needed and a fertile and international business environment, clearly an exceptional environment in the context of an otherwise shrinking national economy.

In the big picture, these most recent developments may disrupt the existing status quo of organizational structures centered around departments and disciplines and move institutions of higher education toward a rearrangement of the "knowledge building blocks," as Clark $(1983,40)$ has also predicted, citing Thomas Kuhn's (1962) landmark 
Structure of Scientific Revolutions. Nonetheless, given the existing evidence from NKUA's published sources, there does not seem to be any tangible or immediately anticipated major change of its organizational structure.

Administration support structures and primary processes/centers of excellence at NKUA

In times of economic turbulence, one of the most standard governmental and institutional responses in Greece has traditionally been administrative support cutbacks (Louloudis 2010). Recently, the reduction in administrative personnel from 2009 until 2016 has reached $30 \%$ on a national average (Ministry of Education 2016, 20-21), and within NKUA, in particular, nearly 50\%, from 1,361 to 761 administrative members (NKUA 2016, 24).

The effects of this decline in administrative support on the execution of primary processes can be read between the lines of NKUA's manifesto. From the entire range of primary processes (teaching and learning, research, and assessment), only research, a process that by definition relies less on administrative support and more on library and physical resources (Swann 2011), receives attention in The National and Kapodistrian University of Athens: A Self-Portrait (2016). Of course, research, according to NKUA (2016, 19-22), is intended to be intertwined with teaching, while students are encouraged to develop research skills and contribute actively to the identification, construction, and promotion of knowledge via academic activities and published scholarship. What is more, research is also directly connected to economic development through "establishments of patents and spin-off companies" (NKUA 2016, 20), with a detailed list 
of the revenue streams from the EU, the European Commision (EC), and the National Strategic Reference Framework (NSRF), as well as nongovernmental third parties. However, the document does not explain the means by which the connection between economic development and research and teaching is supposed to be encouraged or mapped out at an organizational or administrative level, leaving room for doubt about both the prominence of administrative support in this process and the possession of administrative know-how or technical skills in the execution of this process.

This potential lack of administrative know-how and support is evident, as well, in the fact that this document does not address how and at what level administrators might facilitate the organizational process. This absence of an organizational rationale prevents us from determining whether an effective approach will stem from a centralization or decentralization of organizational structures. As a result, it appears that primary processes, such as teaching and learning, are either devalued or taken for granted and assumed at this institution due to the overarching constitutional mandate of the country (Greek Constitution [1975] 2008, Unit 2 Article 16). ${ }^{10}$ However, students' rights are not explicitly promoted in any fashion, nor is any concrete agenda established for the promotion of any explicit teaching and learning strategies via administrative support. ${ }^{11}$ Inevitably, then, assessment is also left out, undercutting any attempt to engage and eventually align with learning outcomes that are promoted in the European higher education arena and provisioned by the Bologna process (London Communiqué 2007, 2; Sweeney 2010; Sin 2014).

It should be noted, however, that this overall lack of administrative support structures does not prevent NKUA from occasionally developing pockets of excellence, 
which seem to operate on a rather decentralized and autonomous level. A prime example of this is The Jean Monnet European Center of Excellence (JMC; see http://www.jmc.uoa.gr), a rather exceptional research program within the structure of this university that functions under the auspices of the European Commission; the Commission negotiates European Governance, as well as Greek European and foreign policy, with a particular focus on European agricultural development, European tourism, and European maritime policy. The striking features of this center of research excellence include its constant media presence, its vibrant intellectual community—manifested mainly via the continuous organization of both conferences and competitive-access certification seminars and educational programs - and its successful attraction of European and national funding for sponsoring research positions, internships, and broader collaborations with national and foreign partners. It also develops synergetic relationships with both Greek and foreign institutions, including the Anna Lindh foundation in Alexandria, the Wilfred Martens think tank, and the Employment and Career Unit of Democritus University of Thrace. Finally, it publishes books and working papers, offers internships, and occasionally hires assistant researchers, thus comprising a research and administration unit. In that respect, the JMC is a great example of a complete, executivelike organizational structure, which is an exception to, and perhaps a creative reflective foil for, the functions and structure of NKUA's broader organization. Indeed, after careful inspection of NKUA's policy documents and embedded websites, we can safely infer that this particular center of excellence is representative neither of the standards of the primary processes that are upheld in this institution generally nor of its typical organizational function. It is a good example, however, of how a single unit can grow to 
achieve some organizational completeness against the grain, achieving transparency and measurable results within a broader embedded environment of what I maintain is a bottom-heavy incompleteness.

Organizational incompleteness: NKUA as a Diophantine equation

So far, I have examined how NKUA functions as an organizational entity by analyzing the way it directs itself on four key governance axes, the way it organizes itself around its basic structural units, and the way it provides administrative support for its operating primary processes. Now I turn to the principal issue of this paper, that is, the extent to which NKUA is a complete organization.

For reasons of brevity and due to the limited scope of the present study, I engage here with a short but robust and representative set of sources (Brunsson and SahlinAndersson 2000; Krücken and Meier 2006; Seeber et al. 2015) ${ }^{12}$ to clarify the organizational status of NKUA. Perhaps the most reliable definition of a "complete organization" comes from Nils Brunsson and Kerstin Sahlin-Andersson (2000, 723-724), who maintain that to be conceived as complete and real, organizations need to possess three elements: a) a distinct, nonreproducible identity within a given field of activities; b) a sense of organizational coordination (which implies hierarchical relationships); and c) a sense of self-ordained, rational, and actionable goals, along with strategies to perpetrate them. ${ }^{13}$ Eventually, to paraphrase both Brunsson and Sahlin-Andersson (2000) and Marco Seeber et al. (2015), universities have to decide whether they are independent and sovereign actors or pawns on the chessboard of other actors. Where would we then 
situate NKUA with regard to these three elements of individual institutional agencynamely, identity, hierarchy, and rationality?

First, let us turn to identity, that is, the institutional struggle to establish boundaries and be special within a field of activities, as well as to control internal resources (Maassen 2003; Stensaker 2004; Seeber et al. 2015). Established in 1837 as the Othonian University, NKUA is the oldest and largest university of Greece, with a long historical lineage, which reinforces a sense of resilience, path-dependency, and special identity (Musselin 2004, 2007; Krücken and Meier 2006). However, NKUA does not have significant control over its financial resources and operates within a fiscally restricted environment (NKUA 2016, 35), which restrains its nominal agency. What is more, NKUA, as is the case throughout Greece, is currently suffering from significant brain drain (Ministry of Education 2016, 55; NKUA 2016, 42), restraining further its control over its human resources. Hence, its organizational identity and the stability it requires do not appear to be settled.

Next, regarding hierarchy, that is, the reinforced sense of leadership via causal chains of command and a clear sense of control over tasks and duties (Brunsson and Sahlin-Andersson 2000; Seeber et al. 2015), NKUA presents mixed findings. Given its triple and democratic distribution of power to the Rector, the Senate, and the Councilvia a system of mutual checks and balances—-hierarchies are reduced to a more horizontal and egalitarian paradigm, undercutting any sense of executive-like, causal chains of command and promoting rather a sense of "bottom-heavy" participation (Tierney 2004), where the different power agents have little actual impact and may in fact cancel one other out. However, one may argue, democratic power is power nonetheless, 
and NKUA does promote a vision and strategic direction in its manifesto (NKUA 2016, 2-3), which supports a sense of agency and discourse control of a particular number of agents over others (MacRae and Whittington 1997; Tierney 2012). Yet such hierarchies do not seem to be directly inspired by executive, top-down models.

Last, regarding rationality — that is, setting objectives and measuring performances against existing standards ${ }^{14}$ _NKUA does display through its mission and manifesto a series of objectives and goals. However, besides its emphasis on research, which is by design quantifiable by several existing academic performance metrics (Altanopoulou, Dontsidou, and Tselios 2012; NKUA 2016, 19-22), NKUA presents neither ways and standards by which performance will be measured and quantified nor attempts to situate itself within existing global scripts of ranking and institutional competition (Krücken and Meier 2006; Tuchman 2009). What is more, there are no external hard mechanisms that could enforce such objectives and goals; on the contrary, NKUA (like the entirety of Greek higher education) seems to suffer from deeply rooted and persistent problems of clientelism (Keridis and Sfatos 1998; Papandreou 1998; Papadoulis 2006; OECD 2011; Papadimitriou 2011a; Argyriades 2013; Fukuyama 2014; Ioannidis 2015, 2016), which has prevented it from successfully reforming itself by favoring the interests of academic elites, bringing to mind the seminal conceptualization of Clark's (1983) triangle of market, state authority, and academic oligarchy as a way of articulating a healthy balance between the competing logics that underrun any academic institution. This fact, in turn, undercuts any attempts to elevate transparency, efficiency, effectiveness, and rationality in recruitment, spending, and other operational practices (Keridis and Sfatos 1998; Papadoulis 2006). ${ }^{15}$ Such clientelism has been a persistent 
feature in the whole spectrum of the labor market in Greece, which has, in turn, also hampered the stronger establishment of ties between universities and industry. ${ }^{16}$ Rationality and clientelism are mutually exclusive phenomena (Menon, Saiti, and Socratous 2007), and the latter decisively undermines any claims to NKUA's organizational completeness.

\section{Conclusion}

Presented through its self-portrait, its website, and the ministerial report, NKUA displays several conflicting tendencies relating to the dynamics of its organizational completeness, preventing us from drawing entirely unambiguous conclusions. Holistically examined through four key governance dilemmas, its self-professed organizational and administrative structure, as well as through the basic conceptual categories of identity, hierarchy, and rationality, the evidence seems to indicate that NKUA is rather inclined toward a model of organizational incompleteness and institutionally driven, symbolically charged organizational logics, promoting a sense of public service and underplaying the global scripts of managerial, executive logics. As it is the case with the preponderance of public higher education institutions internationally, financial restraints and accelerated technological advances do present a rival discourse to the existing practices and will continue to challenge NKUA's organizational outlook, forcing it to reexamine itself (Ministry of Education 2016, 55-56). And in times of graver financial hardship and lower public trust, as in the present case of Greece (Fukuyama 2014), macroscopic and cognitively taxing matters of public good and positive public externalities, such as higher 
education, may be challenged or overlooked (Gumport 2000; Rothman, Kelly-Woessner, and Woessner 2011). As the flagship report of the World Bank entitled "Mind, Society, and Behavior" $(2015,80-97)$ argues, resting on decades of sound experimental research (Ariely 2008; Kahneman 2011; Mani et al. 2013; Mullainathan and Shafir 2013), financial strain consumes cognitive resources, creates more narrow-sided mental frameworks, and prevents decision-makers from reaching consistent decisions and envisioned development aims. Nevertheless, like a Diophantine equation designed to remain incomplete, NKUA's organizational completeness may remain dynamically open. Perhaps this is not such a bad thing, for its dynamic organizational openness may also be considered its evolutionary advantage, allowing NKUA to adapt and persist over time and - to paraphrase Clark $(1983,184)$, citing Antony Downs $(1967,20)$ - to "die hard."

UNIVERSITY OF OSLO

\section{NOTES}

Acknowledgments. I would especially like to thank the JMGS's anonymous reviewers, Elizabeth Davis, Tom Gallant, the Iowa-Oslo Research Collaboration, and Peter Maassen for their support and scholarly input.

${ }^{1}$ Prichard and Willmott (1997) argue that universities are a mix of organizing practices, with significant resilience. Spoelstra (2007) provides an in-depth analysis of the philosophical premises of what constitutes the qualia of an organization, with a robust 
bibliography of relevant sources.

2 This is true of all organizations in general, namely that, if functional, they may not be intrinsically identical; in other words, features and categories that accurately describe one organization of a similar nature and mission might be of little help for another (Brunsson and Sahlin-Andersson 2000, 723).

${ }^{3}$ For a poised and constructive garbage-can theory analysis, see Hearn and McLendon 2012, 52-53.

${ }^{4}$ For the arguable uniqueness of the university as an organization due to the openended nature of the technologies of knowledge production, see the landmark study of Musselin 2007 (first presented in Musselin 2004). Krücken and Meier (2006), following Musselin (2004), maintain that "enacting the common script of "turning the university into an organizational actor' will produce very heterogeneous outcomes," corroborating Musselin's view on the importance and unforeseeable consequences of history and pathdependencies regarding the attainment of organizational status. On the contrary, Seeber et al. (2015) remain equivocal as to how special institutions of higher education are as organizations. Bastedo (2012), following the influential work of Abbott (1998) on the top organizations of the professional prestige hierarchy (top consulting firms, law businesses, hospitals), offers an interesting insight into the understanding of universities as organizations by turning the problem on its head. Rather than examining how higher education is becoming more like business, he argues that "the reverse is more probably true: business is becoming more like higher education" (Bastedo 2012, 4). A similar view on the fluidity of business organizations and the difficulty of determining chains of cause and effect in organizational structure and output is found in de Waal, Kourtit, and 
Nijkamp 2009.

${ }^{5}$ Publicly accessible policy documents from NKUA are a very scarce commodity. For the difficulty of documentation of the Greek higher education procedures, see Papadimitriou 2011a.

${ }^{6}$ For a more detailed layout of the mission of NKUA, see Appendix 1. For the intricate role of the Greek Constitution in describing and prescribing higher education policies in Greece, see Psacharopoulos 2003; Papadimitriou 2011a, 2011 b.

${ }^{7}$ See Benos 2003 for a thorough analysis of the implications of this law.

${ }^{8}$ For a detailed presentation of the contradiction between public and private missions, see Gumport 2000.

${ }^{9}$ Reminiscent of Clark's famous turn of phrase "knowledge as the university's basic building block" $(1983,37)$ See also Probst et al. 2002 for modern takes on knowledge management.

${ }^{10}$ This is a notoriously controversial legal locus; see Psacharopoulos 2003, with comprehensive bibliography.

${ }^{11}$ The enhancement of teaching practices is mentioned briefly in one paragraph (51-52) of the Ministry document and not in The National and Kapodistrian University of Athens: A Self-Portrait. It mentions the design of teaching plans, the mobility of faculty for engaging with different teaching practices, and the use of digitizing/new technologies in teaching.

${ }^{12}$ The debate revisits the classic sociological study of Weber 1968.

${ }^{13}$ See also Krücken and Meier $(2006,241)$, who maintain that an organization is an integrated, goal-oriented entity that can be held responsible for its actions. 
${ }^{14}$ See Seeber et al. 2015. For a different and interesting formulation of what rationality entails, see also the process of "enacting contemporary scripts" and being held accountable for them in Krücken and Meier 2006, 243.

${ }^{15}$ Keridis and Sfatos $(1998,174)$ call the Greek university "a behemoth," unable to respond to the shifting demands, and dominated by strong interest groups that are reluctant to face competition, responsibility, accountability, and meritocracy (see also Papadimitriou 2011a, 124).

${ }^{16}$ On Greek clientelism, see Papadoulis 2006; Fukuyama 2014, 95-107; Trantidis 2016. On Greek university clientelism, as well as mediocracy over meritocracy logics, see Papadoulis 2006; Ioannidis 2015, 2016; Trantidis 2016.

\section{REFERENCES CITED}

Abbott, Andrew. 1988. The System of Professions: An Essay on the Division of Expert Labor. Chicago: Chicago University Press.

Altanopoulou, Panagiota, Maria Dontsidou, and Nikolaos Tselios. 2012. "Evaluation of 93 Major Greek University Departments Using Google Scholar.” Quality in Higher Education 18 (1): $111-137$.

Argyriades, Demetrios. 2013. "Greek Exit from the Crisis-A Pressing and Much-Needed Public Service Reform.” Social Sciences 2 (2): 78-90.

Ariely, Dan. 2008. Predictably Irrational: The Hidden Forces That Shape Our Decisions. New York: HarperCollins.

Asderaki, Foteini. 2009. "The Impact of the Bologna Process on the Development of the Greek 
Quality Assurance System.” Quality in Higher Education 15 (2): 105-122.

2 Bastedo, Michael, ed. 2012. The Organization of Higher Education: Managing Colleges for a 3 New Era. Baltimore, MD: Johns Hopkins University Press.

4 Becher, Tony, and Paul Trowler. 2008. Academic Tribes and Territories: Intellectual Enquiry and the Culture of Disciplines. Buckingham: Open University Press.

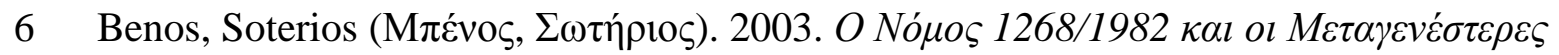

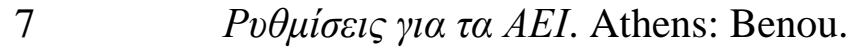

8 Brown, M. Christopher. 2010. Organization and Governance in Higher Education. 6th ed. New $9 \quad$ York: Pearson Learning Solutions.

10 Brunsson, Nils. 1989. The Organization of Hypocrisy: Talk, Decisions, and Actions in 11 Organizations. Chichester: Wiley.

12 , and Kerstin Sahlin-Andersson. 2000. "Constructing Organizations: The Example of 13 Public Sector Reform.” Organization Studies 21 (4): 721-746.

14 Clark, Burton. 1983. The Higher Education System: Academic Organization in Cross15 National Perspective. Berkeley and Los Angeles: University of California Press. $16 \longrightarrow$ ed. 1998. Creating Entrepreneurial Universities: Organizational Pathways of 17 Transformation. Oxford: Oxford University Press.

18 Clegg, Stewart, David Courpasson, and Nelson Phillips. 2006. Power and Organizations. 19 Thousand Oaks, CA: Sage.

20 Cohen, Michael D., and James C. March. 1974. Leadership and Ambiguity: The American $21 \quad$ College President. New York.

22 - and Johan Olsen. 1972. “A Garbage Can Model of Organizational Choice.” 23 Administrative Science Quarterly 17: 1-25. 
1 de Waal, Andre, Karima Kourtit, and Peter Nijkamp. 2009. "The Relationship between the Level of Completeness of a Strategic Performance Management System and Perceived Advantages and Disadvantages." International Journal of Operations and Production Management 29 (12): 1242-1265.

Downs, Antony. 1967. Inside Bureaucracy. Boston: Little, Brown and Company.

Enders, Jürgen. 2002. Governing the Academic Commons: About Blurring Boundaries, Blistering Organizations, and Growing Demands. Enschede: University of Twente.

European Parliament. 2015. "Youth Unemployment in Greece: Situation Before the Government Change.” Employment and Social Affairs Briefing. Accessed 20 August 2017. http://www.europarl.europa.eu/RegData/etudes/BRIE/2015/542220/IPOL_BRI(2015)542 220_EN.pdf.

Evans, Christina, and Leonard Holmes. 2013. Re-Tayloring Management: Scientific Management a Century On. Farnham, Surrey: Routledge.

Exadaktylos, Theophanes, and Nikolaos Zahariadis. 2014. "Quid pro Quo: Political Trust and Policy Implementation in Greece during the Age of Austerity." Politics and Policy 42 (1): 160-183.

Fohrmann, Oliver. 2016. Im Spiegel des Geldes: Bildung und Identität in Zeiten der Ökonomisierung. Bielefeld: transcript.

Frølich, Nicoline. 2011. "Multi-Layered Accountability: Performance-Based Funding of Universities.” Public Administration 89 (3): 840-859.

Fukuyama, Francis. 2014. Political Order and Political Decay. Vol 2, From the French Revolution to the Present. New York: Farrar, Straus, and Giroux.

Gornitzka, Åse. 1999. “Governmental Policies and Organizational Change in Higher Education.” 
Higher Education 38 (1): 5-31.

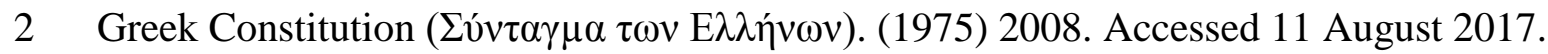
http://www.hellenicparliament.gr/UserFiles/8c3e9046-78fb-48f4-bd82bbba28ca1ef5/SYNTAGMA.pdf.

5 Gumport, Patricia. J. 2000. “Academic Restructuring: Organizational Change and Institutional 6 Imperatives." Higher Education 39 (1): 67-91.

7 . 2012. "Strategic Thinking in Higher Education Research.” In The Organization of Higher Education: Managing Colleges for a New Era, edited by Michael Bastedo, 1841. Baltimore, MD: Johns Hopkins University Press.

Hearn, James C., and Michael C. McLendon. 2012. “Governance Research.” In The

1
Organization of Higher Education: Managing Colleges for a New Era, edited by Michael Bastedo, 45-85. Baltimore, MD: Johns Hopkins University Press.

Henkel, Mary. 2000. Academic Identities and Policy Change in Higher Education. Philadelphia,

15 Innovathens. 2016. "What is Innovathens?" Accessible at:

16 https://www.innovathens.gr/innovathens-en-2/

17 Ioannidis, John. 2015. “Mediocracy Versus Meritocracy.” Ted ${ }^{\mathrm{X}}$ Academy 2015. Accessed 18 August 2017. https://youtu.be/KQtpEoS6W44.

Jaeger, Angelika, and Johannes Kopper. 2014. "Third Mission Potential in Higher Education:

23 Kahneman, Daniel. 2011. Thinking, Fast and Slow. New York: Farrar, Straus, and Giroux. 
1 Keridis, Dimitris, and Chrysostomos Sfatos, eds. 1998. Greek Higher Education: Prospects for 2 Reform. New York: Pella.

3 Krücken, Georg, and Jon Meier. 2006. "Turning the University into an Organizational Actor." In 4 Globalization and Organization: World Society and Organizational Change, edited by G.

5 S. Drori, J. W. Meyer, and H. Hwang, 241-257. Oxford: Oxford University Press

6 Kuhn, Thomas S. 1962. The Structure of Scientific Revolutions. Chicago: University of Chicago $7 \quad$ Press

8 Labrianidis, Lois. 2014. "Investing in Leaving: The Greek Case of International Migration of $9 \quad$ Professionals." Mobilities 9 (2): 314-335.

10 Larsen, Ingvild M., Peter Maassen, and Bjørn Stensaker. 2009. "Four Basic Dilemmas in 11 University Governance Reform.” Higher Education Management and Policy 21 (3): 1$12 \quad 18$.

13 Law 1268/1982. 1982. "On the Structure and Function of Higher Education Institutions".

14 Official Journal of the Hellenic Republic 87.1 July.

15 Law 3374/2005. 2005. "Quality Assurance in Higher Education: Establishment of the European

16 Credit Transfer and Accumulation System and Diploma Supplement." Official Journal of 17 the Hellenic Republic 189. 2 August.

18 Law 4009/2011. 2011. "Structure, Function, Quality Assurance of Studies, and Internationalization of Higher Education Institutions". Official Journal of the Hellenic

21 London Communiqué. 2007. "Towards the European Higher Education Area: Responding to Challenges in a Globalised World." 18 May.

23 Louloudis, Leonidas. 2010. “The ‘Underfunding' of Universities: Yes, Maybe, Maybe Not?” In 
The University Today: Aspects of the Crisis and Adjustment Steps, edited by A. Dimitropoulos, N. Maravejias, and A. Mitsos, 148-171. Athens: Themelio.

Maassen, Peter. 2003. "Shifts in Governance Arrangements: An Interpretation of New Management Structures in Higher Education.” In The Higher Education Managerial Revolution?, edited by A. Amaral, V.L. Meek, and I.M. Larsen, 31-53. Dordrecht: Springer.

— , and Johan P. Olsen, eds. 2007. University Dynamics and European Integration. Dordrecht: Springer

MacRae, Duncan, and Dale Whittington. 1997. Expert Advice for Policy Choice: Analysis and Discourse. Washington, DC: Georgetown University Press.

Magolda, Peter. M. 2016. The Lives of Campus Custodians: Insights into Corporatization and Civic Disengagement in the Academy. Virginia: Stylus.

Mani, Anandi, Sendhil Mullainathan, Eldar Shafir, and Jiaying Zhao. 2013. "Poverty Impedes Cognitive Function.” Science 341 (6149): 976-980.

March, James G. 1984. "How We Talk and How We Act: Administrative Theory and

Administrative Life." In Leadership and Organizational Culture: New Perspectives on

Administrative Theory and Practice, edited by T.J. Sergiovanni and J.E. Corbally, 18-35.

18 Urbana, IL: University of Illinois Press.

9 - and Johan P. Olsen. 1989. Rediscovering Institutions: The Organizational Basis of

Politics. New York: Free Press.

1 Menon, Maria Eliophotou, Anna Saiti, and Michalis Socratous. 2007. "Rationality, Information

2 Search and Choice in Higher Education: Evidence from Greece." Higher Education 54

3 (5): 705-721. 
1 Meyer, John W. 2009. "Reflections: Institutional Theory and World Society.” In World Society:

2 The Writings of John W. Meyer, edited by G. Krücken and G.S. Dror, 36-66. Oxford:

3 Oxford University Press.

$4 \longrightarrow$, and Brian Rowan. 1977. "Institutionalized Organizations: Formal Structure as Myth and

$5 \quad$ Ceremony.” The American Journal of Sociology 83 (2): 340-363.

6 - and W. Richard Scott. 1983. Organizational Environments: Ritual and Rationality.

$7 \quad$ Berkeley and Los Angeles: University of California Press.

8 Ministry of Education. 2016. A Strategy for Higher Education in Greece: 2016-2020. Accessed

921 August 2017.

10 https://www.minedu.gov.gr/publications/docs2016/\%CE\%A3\%CE\%A4\%CE\%A1\%CE

$11 \quad \% 91 \% \mathrm{CE} \% \mathrm{~A} 4 \% \mathrm{CE} \% 97 \% \mathrm{CE} \% 93 \% \mathrm{CE} \% 99 \% \mathrm{CE} \% 9 \mathrm{~A} \% \mathrm{CE} \% 97 \% \mathrm{CE} \% 91 \% \mathrm{CE} \% 95 \% \mathrm{C}$

12 E\%99_-2016_09_10.pdf.

13 Mullainathan, Sendhil, and Eldar Shafir. 2013. Scarcity: Why Having Too Little Means So Much.

$14 \quad$ New York: Times Books.

15 Muller, Johan, and Michael Young. 2014. "Disciplines, Skills and the University." Higher

$16 \quad$ Education 67 (2): 127-140.

17 Musselin, Christine. 2004 ““Are Universities Specific Organizations?”” Paper presented at the

$18 \quad$ Conference Towards a Multiversity? Universities between National Traditions and

19 Global Trends in Higher Education, Institute for Science and Technology Studies,

20 Bielefeld University, 11-13 November, 2004.

21 . 2007. “Are Universities Specific Organizations?” In Towards a Multiversity?

22 Universities between Global Trends and National Traditions, edited by G. Krücken, A.

23 Kosmützky, and M. Torka, 63-84. Bielefeld: transcript. 
1 Neave, Guy. 1998. “The Evaluative State Re-Considered.” European Journal of Education 33:

2

4

5

6

7 265-284.

National and Kapodistrian University of Athens (NKUA). 2016. The National and Kapodistrian University of Athens: A Self-Portrait. Athens: National and Kapodistrian University of Athens. Accessed 10 August 2017. http://www.uoa.gr/fileadmin/user_upload/PDFfiles/organa/UoAFylladiov2.pdf.

National and Kapodistrian University of Athens (NKUA). (n.d.). "Mission, Policies, and

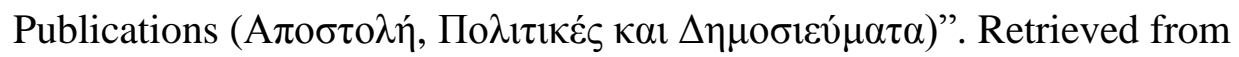
https://www.uoa.gr/to_panepistimio/apostoli_politikes_kai_dimosieymata/

Oliver, Christine 1991. "Strategic Responses to Institutional Processes." Academy of Management Review 16 (1): 145-179.

Olsen, Johan P. 2001. "Garbage Cans, New Institutionalism, and the Study of Politics." American Political Science Review 95: 191-198.

. 2009. "Change and Continuity: An Institutional Approach to Institutions of Democratic Government." European Political Science Review 1 (1): 3-32.

OECD (Organization for Economic Cooperation and Development). 2011. Successful Performers and Successful Reformers in Education: Education Policy Advice for Greece. Paris: OECD.

Paliktzoglou, Vasileios, Charalampous Giousmpasoglou, and Evangelia Marinakou. 2016.

"Economic Crisis and Higher Education in Greece." In Impact of Economic Crisis on Education and the Next-Generation Workforce, edited by P. Ordóñez de Pablos and R.D. Tennyson, 120-148. Hershey, PA: IGI Global.

Papadimitriou, Antigone 2011a. "The Enigma of Quality in Greek Higher Education: A Mixed 
Methods Study of Introducing Quality Management into Greek Higher Education.” PhD diss., Twente University, Enschede.

_.2011b. "Reforms, Leadership, and Quality Management in Greek Higher Education." Tertiary Education and Management 17 (4): 355-372.

_.2015a. “Academic Identity Formation in Greek Higher Education.” In Academic Identities and the Changing European Landscape, edited by J. Nixon and L. Evans, 239255. London: Bloomsbury.

_.2015b. "Coping with the Crisis: Academic Work and Changes in Greek Higher Education." In The Relevance of Academic Work in Comparative Perspective, edited by W.K. Cummings and U. Teichler, 40-57. Dordrecht: Springer.

Papadoulis, Konstantinos J. 2006. "Clientelism, Corruption and Patronage in Greece: A Public Administration Approach.” Teaching Public Administration 26 (1): 13-24.

Papandreou, George 1998. “Toward the 21st Century: Greek Education in Transition.” In Greek Higher Education: Prospects for Reform, Vol. 1, edited by D. Keridis and C. Sfatos, 1926. New York: Pella.

Pascarella, Ernest T. 2006. "How College Affects Students: Ten Directions for Future Research.” Journal of College Student Development 47 (5): 508-520.

Perrow, Charles 1985. "Overboard with Myth and Symbols." American Journal of Sociology 91 (1): 151-155.

Pesmatzoglou, Stephanos 1994. "Government, Ideology, and the University Curriculum in Greece.” European Journal of Education 29 (3): 291-304.

Probst, Gilbert, Steffen Raub, and Kai Romhardt. 2002. Managing Knowledge: Building Blocks for Success. Chichester: Wiley. 
1 Prichard, Craig, and Hugh Willmott. 1997. "Just How Managed is the McUniversity?"

$2 \quad$ Organization Studies 18 (2): 287-316.

3 Psacharopoulos, George 2003. "The Social Cost of an Outdated Law: Article 16 of the Greek

4 Constitution.” European Journal of Law and Economics 16 (2): 123-137.

5 Pusser, Bria, Sheila Slaughter, and Scott Loring Thomas. 2006. "Playing the Board Game: An

6 Empirical Analysis of University Trustee and Corporate Board Interlocks." Journal of $7 \quad$ Higher Education 77 (5): 747-775.

8 Rothman, Stanley, April Kelly-Woessner, and Matthew Woessner. 2011. The Still

9 Divided Academy: How Competing Visions of Power, Politics, and Diversity Complicate

10 the Mission of Higher Education. Lanham, MD: Rowman and Littlefield.

11 Santiago, Paulo, Karine Tremblay, Ester Basri, and Elena Arnal. 2008. Tertiary Education for 12 the Knowledge Society. Paris: OECD.

13 Seeber, Marco. 2013. "Efficacy and Limitations of Research Steering in Different Disciplines." $14 \quad$ Studies in Higher Education 38 (1): 20-38.

$15 \longrightarrow$, Benedetto Lepori, Martina Montauti, Jürgen Enders, Harry de Boer, Elke Weyer, Ivar 16 Bleiklie, Kristin Hope, Svein Michelsen, Gigliola Nyhagen Mathisen, Nicoline Frølich, 17 Lisa Scordato, Bjørn Stensaker, Erica Waagene, Zarko Dragsic, Peter Kretek, Georg 18 Krücken, António Magalhães, Filipa M. Ribeiro, Sofia Sousa, Amélia Veiga, Rui 19 Santiago, Giulio Marini, and Emanuela Reale. 2015. "European Universities as Complete 20 Organizations? Understanding Identity, Hierarchy and Rationality in Public 21 Organizations." Public Management Review 17 (10): 1444-1474.

22 Sin, Christina. 2014. "Lost in Translation: The Meaning of Learning Outcomes across National 23 and Institutional Policy Contexts." Studies in Higher Education 39 (10): 1823-1837. 
1 Spoelstra, Sverre. 2007. What is Organization? Lund: Lund Business Press.

2 Stamoulas, Aristotelis. 2006. "Greece Before the Bologna Process: Confronting or Embracing

3 Quality Assurance in Higher Education?" Higher Education Policy 19 (4): 433-445.

4 Stensaker, Bjørn. 2004. "The Transformation of Organizational Identities: Interpretations of

5 Policies Concerning the Quality of Teaching and Learning in Norwegian Higher

$6 \quad$ Education.” PhD diss., Twente University, Enschede.

7 Swann, Joanna. 2011. Learning, Teaching, and Education Research in the 21st Century: An

8 Evolutionary Analysis of the Role of Teachers. London: Bloomsbury.

9 Sweeney, Simon. 2010. Bologna Process: Responding to the Post-2010 Challenge. York: Higher

$10 \quad$ Education Academy.

11 Tierney, William, ed. 2004. Competing Conceptions of Academic Governance: Negotiating the

$13 \longrightarrow$ 2012. "Creativity and Organizational Culture." In The Organization of Higher

14 Education: Managing Colleges for a New Era, edited by Michael Bastedo, 160-180.

15 Baltimore, MD: Johns Hopkins University Press.

16 Trantidis, Aris. 2016. Clientelism and Economic Policy: Greece and the Crisis. Abingdon:

$17 \quad$ Routledge.

18 Tuchman, Gaye. 2009. Wannabe U: Inside the Corporate University. Chicago: University of 19 Chicago Press.

20 Weber, Max. 1968. Economy and Society: An Outline of Interpretive Sociology. Berkeley and 21 Los Angeles: University of California Press.

22 Weick, Karl E. 1976. "Educational Organizations as Loosely Coupled Systems.” Administrative 23 Science Quarterly 21 (1): 1-19. 
— 1995. Sense Making in Organizations. Thousand Oaks, CA: Sage.

2 World Bank. 2015. "World Development Report 2015: Mind, Society, and Behavior.” Washington, DC: World Bank.

4 Zahariadis, Nikolaos 2013. "Leading Reform amidst Transboundary Crises: Lessons from $5 \quad$ Greece.” Public Administration 91 (3): 648-662.

6 - and Theofanis Exadaktylos. 2016. "Policies that Succeed and Programs that Fail:

7 Ambiguity, Conflict, and Crisis in Greek Higher Education." Policy Studies Journal 44

8 (1): 59-82.

9 Zmas, Aristotelis. 2015. "Financial Crisis and Higher Education Policies in Greece: Between 10 Intra- and Supranational Pressures." Higher Education 69 (3): 495-508.

11 Zucker, Lynne G. 1987. “Institutional Theories of Organizations.” Annual Review of Sociology

24 Figure 1: NKUA Organizational Chart (modified). Source: 
1 https://en.uoa.gr/about_us/administration/organizational_chart/.

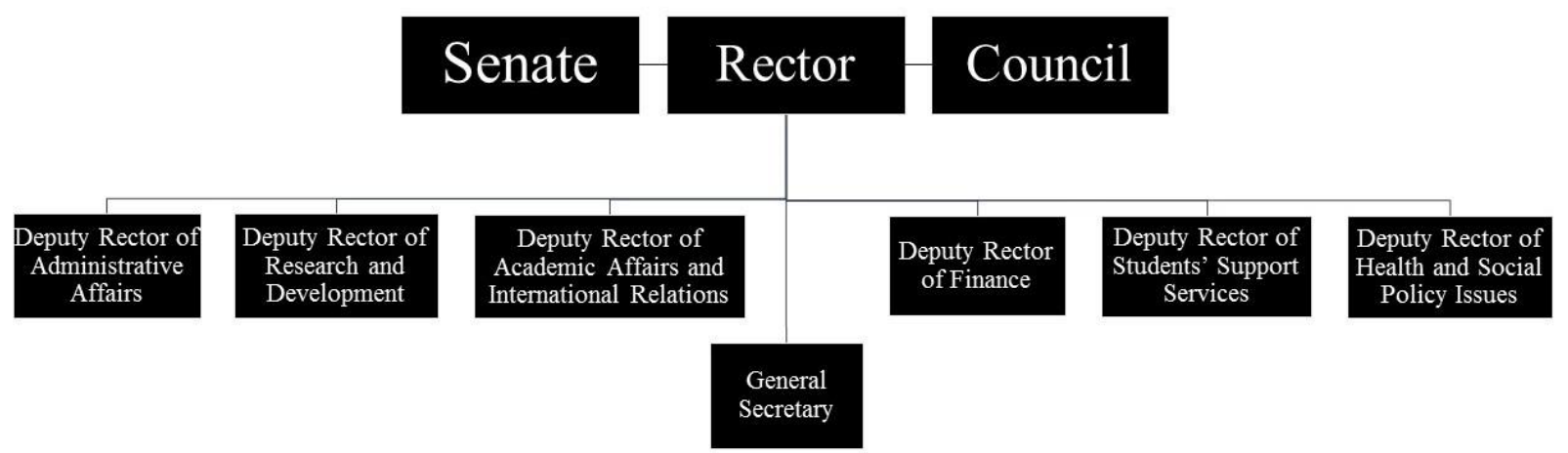

3 Appendix 1: NKUA's Mission, Policies, and Publications (In Greek, with English Translation).

4 Source:[ https://www.uoa.gr/to_panepistimio/apostoli_politikes_kai_dimosieymata/PLEASE

5 PROVIDE A SOURCE].

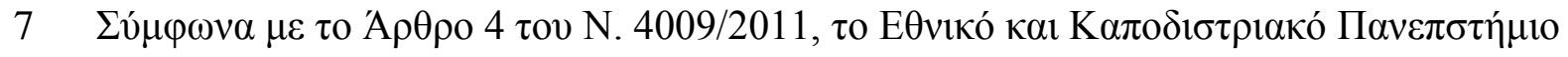

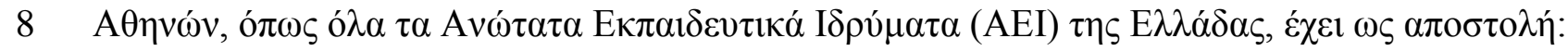

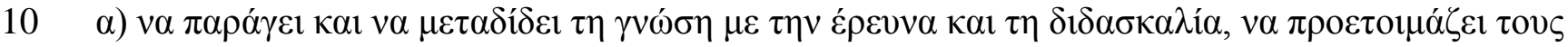

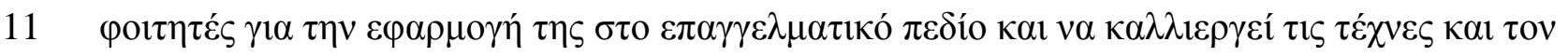

$12 \pi \mathrm{\pi} \lambda \imath \imath \imath \sigma \mu o ́$

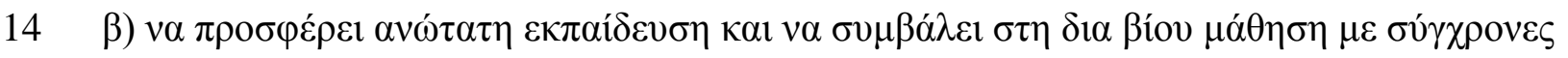

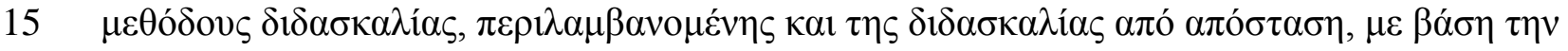

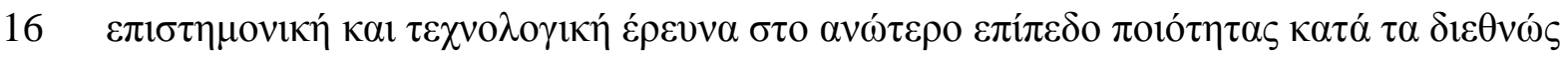

$17 \alpha v \alpha \gamma \nu \omega \rho \imath \sigma \mu \varepsilon \dot{v} \alpha \kappa \rho \imath \eta ́ \rho ı ;$ 


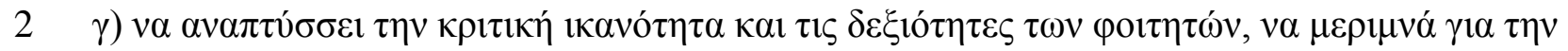

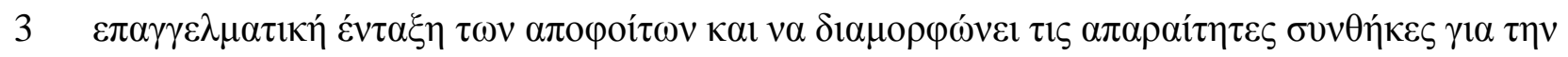

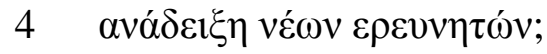

5

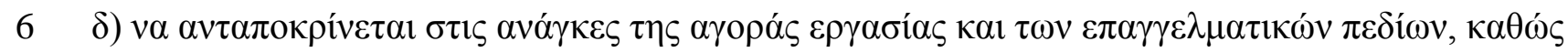

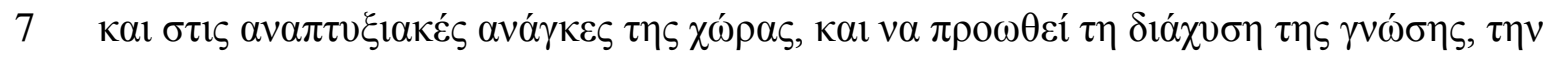

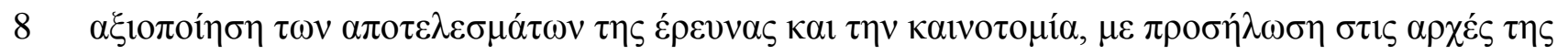

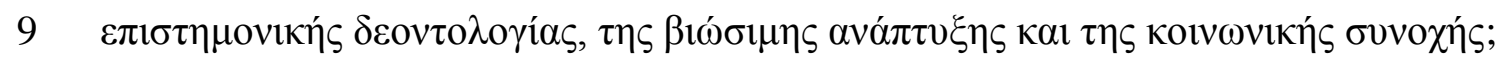

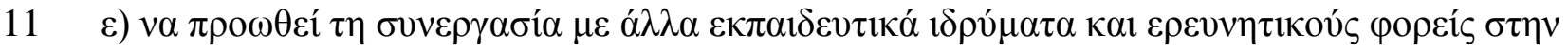

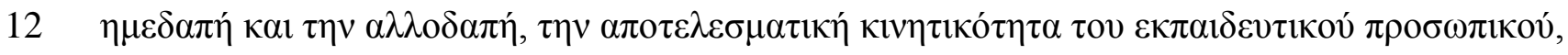

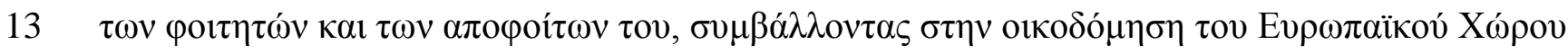

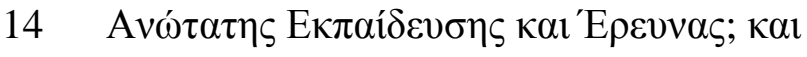

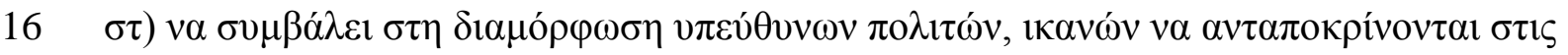

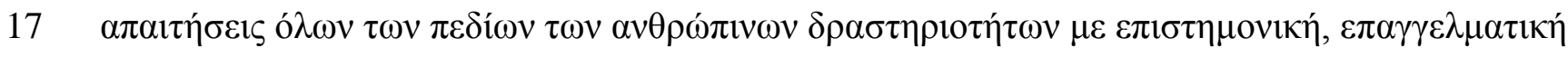

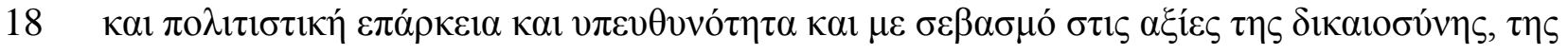

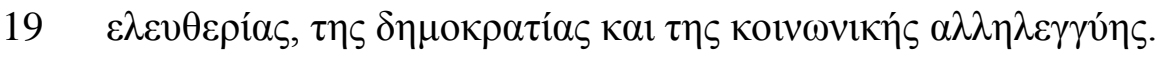

21 In English (translation our own):

23 According to Article 4 of Law 4009/2011, the National and Kapodistrian University of Athens, 
1 like all Higher Education Institutions in Greece, has as its mission to:

3 (A) produce and disseminate knowledge through research and teaching, prepare students for its

4 application in the professional field, and cultivate arts and culture;

6 (B) provide higher education and contribute to lifelong learning through modern teaching

7 methods, including distance learning, based on scientific and technological research at the

8 highest quality level according to internationally recognized criteria;

10 (C) develop students' critical thought and skills, ensure the integration of graduates, and create

11 the necessary conditions for the emergence of new researchers;

13 (D) respond to labor market and occupational needs, as well as to the country's development

14 needs, and promote knowledge diffusion, exploitation of research results and innovation,

15 respecting the principles of scientific ethics, sustainable development, and social cohesion;

17 (E) promote cooperation with other educational institutions and research bodies in the country

18 and abroad, as well as the effective mobility of educational staff, students, and graduates,

19 contributing to the building of the European Higher Education and Research Area; and

21 (F) contribute to the formation of responsible citizens capable of meeting the requirements of all

22 fields of human activities with scientific, professional, and cultural competence and

23 accountability, as well as with due respect for the values of justice, freedom, democracy, and 
1 social solidarity.

2 